\title{
MEASUREMENT OF NITROUS OXIDE EMISSION FROM AGRICULTURAL LAND USING MICROMETEOROLOGICAL METHODS
}

\author{
K. J. HARGREAVES,* F. G. WIENHOLD, † L. KLEMEDTSSON, \\ J. R. M. ARAH,§ I. J. BEVERLAND, $\uparrow$ D. FOWLER,* B. GALLE, \\ D. W. T. GRIFFITH, \| U. SKIBA,* K. A. SMITH,**ף M. WELLING $\dagger$ \\ and G. W. HARRIS**
}

\begin{abstract}
The spatial variability of $\mathrm{N}_{2} \mathrm{O}$ emission from soil makes extrapolation to the field scale very difficult using; conventional chamber techniques $\left(<1 \mathrm{~m}^{2}\right)$. Micrometeorological techniques, which integrate $\mathrm{N}_{2} \mathrm{O}$ fluxes over areas of 0.1 to $1 \mathrm{~km}^{2}$ were therefore developed and compared with chamber methods over arable cropland. Measurements of $\mathrm{N}_{2} \mathrm{O}$ emission from an unfertilised organic soil (reclaimed from the sea in 1879) were made over a $10 \mathrm{~d}$ period at Lammefjord, Denmark. Flux-gradient and conditional sampling techniques were applied using two tunable diode laser spectrometers (TDLs), a Fourier transform infra-red spectrometer (FTIR) and a gas chromatograph (GC). Eddy covariance measurements were also made by the TDLs. Over the $10 \mathrm{~d}$ campaign approximately $5 \mathrm{~d}$ of continuous fluxes by the different methods were obtained. Fluxes determined by eddy covariance were in reasonable agreement, showing a mean flux of $269 \mu \mathrm{g} \mathrm{N} \mathrm{m}^{2} \mathrm{~h}^{-1}$. Flux-gradient techniques measured a mean flux of $226 \mu \mathrm{g} \mathrm{m}^{-2} \mathrm{~h}^{-1}$. The mean flux measured by conditional sampling was $379 \mu \mathrm{g} \mathrm{N} \mathrm{m}^{-2} \mathrm{~h}^{-1}$. The maximum annual emission of $\mathrm{N}_{2} \mathrm{O}$ from this soil system was estimated to be $23.5 \mathrm{~kg} \mathrm{Nha}^{-1}$.
\end{abstract}

Key word index: Eddy covariance, conditional sampling, flux gradient, Bowen ratio, nitrous oxide, greenhouse gas.

\section{INTRODUCTION AND THEORY}

Nitrous oxide $\left(\mathrm{N}_{2} \mathrm{C}\right)$ is one of the important greenhouse gases, accounting for approximately $6 \%$ of radiative forcing in the period 1980-1990 (IPCC, 1990). It has a loag atmospheric lifetime (130 yr; WMO, 1992) and plays an important role in stratospheric chemistry. Present day concentrations are approximately $8 \%$ greater than pre-industrial concentrations. A major contribution to this increase has come from $\mathrm{N}_{2} \mathrm{O}$ emissions from cultivated and fertilised soils, which may be one of the largest individual sources, but estimates of the global source strength are based on sparse data. There is a particular problem in estimating regional or global enuissions when measurements are made over very small areas using chamber techniques. The problem has only recently begun to be addressed (e.g. Smith et al., 1994; Hargreaves et al., 1994) using micrometeorological techniques which provide measurements integrated over field or landscape scales. The rapid development of equipment suitable for making such measurements not only provides a valuable opportunity to improve our estimates of global $\mathrm{N}_{2} \mathrm{O}$ emissions, but also permits comparisons between different micrometeorological methods and conventional chamber techniques.

This paper describes an international experiment which took place in August 1993 at a site in Denmark as a follow up to a similar experiment which took place in April 1992 in central Scotland (Smith et al., 1994; Hargreaves et al., 1994). The objectives of the experiment were: (i) to measure $\mathrm{N}_{2} \mathrm{O}$ emission from arable agricultural land over a range of spatial scales; (ii) to identify the processes controlling $\mathrm{N}_{2} \mathrm{O}$ emission from the site; and (iii) to compare micrometeorological and chamber methods. The bulk of this paper is concerned with the micrometeorological measurements made at the site, but should be read in conjunction with that of Christensen et al. (1995) which 
reports chamber measurements and a study of the process involved in $\mathrm{N}_{2} \mathrm{O}$ production and transport.

\section{METHODS AND STTE DESCRIPTION}

Micrometeorological theory is extensively dealt with in the literature (e.g. Monteith and Unsworth, 1990; Fowler and Duyzer, 1989; Businger, 1986; Businger and Oncly, 1990) so the equations used to calculate $\mathrm{N}_{2} \mathrm{O}$ fluxes are presented without further elaboration:

Flux gradient:

$$
F_{\chi}=-k^{2} \frac{\mathrm{d} u}{\operatorname{din}(z-d)} \frac{\mathrm{d}_{\chi}}{\operatorname{dln}(z-d)} \phi_{\mathrm{m}}^{-1} \phi_{\mathrm{h}}^{-1}
$$

Eddy covariance:

$$
F_{\chi}=\overline{w^{\prime} \chi^{\prime}}
$$

Conditional sampling:

$$
F_{\chi}=\beta \sigma_{\mathrm{w}}\left(\chi_{\mathrm{u}}-\chi_{\mathrm{d}}\right)
$$

where $F_{\chi}=$ trace gas flux $\left(\mu \mathrm{g} \mathrm{N} \mathrm{m}^{-2} \mathrm{~s}^{-1}\right), k=$ von Karman's constant, $u=$ wind speed $\left(\mathrm{ms}^{-1}\right)$ at height $z(\mathrm{~m}), \chi=$ gas concentration $\left(\mu \mathrm{g} \mathrm{N} \mathrm{m}^{-3}\right)$ at height $z(\mathrm{~m}), d=$ zero plane displacement $(\mathrm{m}), w^{\prime}=$ instantaneous deviation of vertical wind speed, $w$, from the mean $\left(\mathrm{ms}^{-1}\right), \chi^{\prime}=$ instantaneous deviation of gas concentration, $\chi$, from the mean $\left(\mu \mathrm{g} \mathrm{m}^{-3}\right), \beta=$ dimensionless coefficient $(\approx 0.56)$ determined from heat flux measurements, $\sigma_{\mathrm{w}}=$ standard deviation of the vertical wind speed $\left(\mathrm{ms}^{-1}\right), \chi_{u}, \chi_{\mathrm{d}}=$ gas concentration in up/downdraughts $\left(\mu \mathrm{g} \mathrm{Nm}^{-3}\right)$, and $\phi_{\mathrm{m}}$ and $\phi_{\mathrm{h}}$ are dimensionless stability corrections. Errors in the calculation of fluxes can arise from variations in air density due to simultaneous sensible and latent heat transfer. Corrections to compensate for such factors described by Webb et al. (1980) were applied where appropriate.

The experiment took place between 18 and 28 August 1993 at a site near the village of Farevejle Stationsby in the Lammefjord region of Sealand, Denmark. The site (at $2 \mathrm{~m}$ below sea level) consisted of a silty clay organic soil reclaimed from the sea in 1879 and planted with a variety of crops (Fig. 1). No nitrogen fertiliser has been applied to the site since reclamation (because of the release of nitrogen from the soil organic matter (Christensen et al., 1995), and the water table is maintained approximately $1 \mathrm{~m}$ below the surface by pumping systems. The predominant fetch was over wheat stubble (height $0.1 \mathrm{~m}$ ) and carrots $(0.4 \mathrm{~m})$, but crops in the immediate vicinity included potatoes (both in leaf and with the leaves burnt off), spinach, onions and unharvested wheat. Despite the heterogeneity of the crops the site offered good micrometeorological conditions, with fetch extending to over $600 \mathrm{~m}$ in all directions.

Gas analysis instruments were housed in four mobile laboratories at the southeastern edge of the stubble field, with the micrometeorological towers placed to the immediate northeast. The towers were placed in two locations according to the Institutes operating them (see Fig. 1).

Location 1 (Institute of Terrestrial Ecology (ITE)/ Scottish Agricultural College $(S A C)$ ) consisted of three towers. A Solent ultrasonic anemometer (model 1021RA) was mounted at a height of $4.9 \mathrm{~m}$ with a $\frac{1}{4}$ gas sampling line running to a TDL spectrometer (Aerodyne Research Inc., MA, U.S.A.; Zahniser et al., 1995). Ten-minute mean $\mathrm{N}_{2} \mathrm{O}$ and sensible heat fluxes were calculated on-line by eddy covariance on a nearcontinuous basis using the PC-based "EddySol" package (Moncrieff et al., 1994). A conditional sampling system (Beverland et al., 1995) was also attached to and controlled by the ultrasonic anemometer. Gas sample lines led back to $25 \ell$ tedlar sample bags, one to collect updraughts, the other for downdraughts. Air samples were analysed using the ITE TDL spectrometer, the IVL (Swedish Environmental Research Institute) FTIR spectrometer (Galle et al., 1994) and the SAC GC (Arah et al., 1994). This method was employed intermittently throughout the experiment, generally making measurements over 30-60 min. The second mast carried a six-point wind profile (Vector Instruments $\mathrm{A} 100 \mathrm{R}$ ) and a five-point gas sampling system $(0.2,0.32,0.63,1.02$ and $1.62 \mathrm{~m})$ from which $5 \ell$ tedlar bags were filled over $30 \mathrm{~min}$ periods. These samples were analysed on the ITE TDL. This sampling was reserved for periods of low wind speed in order to maximise the potential $\mathrm{N}_{2} \mathrm{O}$ concentration gradient and improve the precision of the concentration measurement. The third mast comprised a Bowen-ratio system (Campbell Scientific) to measure the energy balance of the site. The averaging period for both energy balance and wind profile data was $10 \mathrm{~min}$.

Location 2 (IVL/MPI (Max Planck Institute für Chemie)). The IVL equipment comprised a single mast with three sample lines fixed at heights of $0.2,0.5$ and $1.62 \mathrm{~m}$. These lines were sampled semisequentially over a 20 min period and the $\mathrm{N}_{2} \mathrm{O}$ concentration from each height measured by FTIR spectroscopy (Galle $e t$ al., 1994). $\mathrm{N}_{2} \mathrm{O}$ emission was calculated by the fluxgradient technique using the wind profile obtained at location 1 . This system operated near-continuously between 20 and 25 August. Between 25 and 28 August the FTIR was used in other experiments.

The MPI equipment consisted of a Solent ultrasonic anemometer (Model 1012RA) mounted at 3.25 $\mathrm{m}$ with a gas sample line leading back to a TDL spectrometer developed at the Max Planck Institute (Wienhold et al., 1994a). Eddy covariance $\mathrm{N}_{2} \mathrm{O}$ fluxes were measured during the daytime between 23 and 28 August, and half-hour average fluxes were calculated off-line (Wienhold et al., 1994b). On the afternoons of 24 and 26 August the TDL was used to measure concentration gradients in the air sampled from $0.2,0.32,0.5$ and $1.62 \mathrm{~m}$ above the ground over halfhour periods sharing the IVL gradient inlets. Rates of 


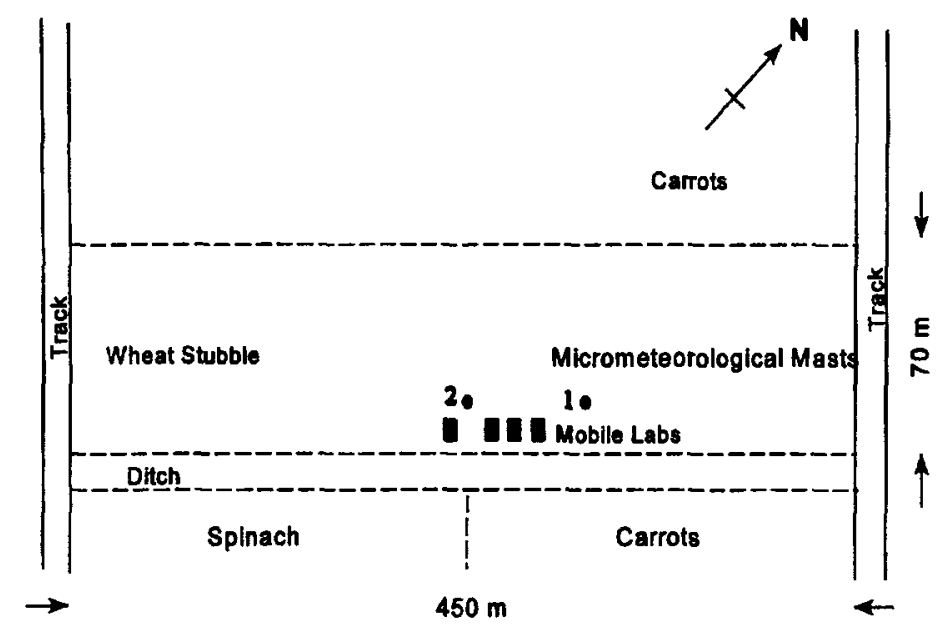

Fig. 1. Site diagram for the Lammefjord Experiment showing position of instruments and crop cover.

$\mathrm{N}_{2} \mathrm{O}$ emission were then calculated by the flux-gradient method.

\section{FLUXX FOOTPRINTS}

In order to compare micrometeorological methods, the area over which the flux is integrated must be known. This depends on sensor height, surface roughness, wind speed and atmospheric stability. Schuepp et al. (1990) derived an analytical approach which compared well with results from a numerical Lagrangian trajectory simulation (Leclerc and Thurtell, 1990). The cumulative normalised contribution to the flux $\left(C_{F}\right)$ is given by

$$
C_{F}=\mathrm{e}^{-\mathrm{U} \phi_{\mathrm{m}}(2-d) / k u_{*} x}
$$

where $U$ is the mean wind speed between the surface and the measurement height $\left(\mathrm{m} \mathrm{s}^{-1}\right), \Phi_{\mathrm{m}}$ is a dimensionless stability constant, $z$ is the measurement height $(\mathrm{m}), d$ the zero plane displacement $(\mathrm{m}), k$ is von Karman's constant $(=0.41), u_{*}$ is the friction velocity $\left(\mathrm{m} \mathrm{s}^{-1}\right)$ and $x$ the distance upwind of the measuring point $(\mathrm{m})$. Figure $2 \mathrm{a}$ illustrates the significance of measurement height on the flux footprint in typical daytime, unstable conditions, using the heights of the sensors in this study. It is clear that the bulk $(80 \%)$ of the flux measured by the profile systems is derived from areas less than $100 \mathrm{~m}$ from the mast. At the other extreme, the ITE eddy covariance system at a height of $4.9 \mathrm{~m}$ derives only about half its fiux from this area. Conversely, Fig. $2 b$ illustrates the effect of stability and wind speed on measurements made by the profile systems described here. In the mildly stable conditions that were observed during most nights, the effective footprint becomes much larger, with $80 \%$ of the flux derived from the area up to $460 \mathrm{~m}$.

\section{RESULTS AND DISCUSSION}

\section{Energy balance}

The soil at this site was very freely drained in the upper layers leading to a soil surface which dried rapidly after rainfall. Figure 3 shows a typical energy balance measured by the Bowen-ratio system on a dry day when fetch was over the stubble, with $80 \%$ of the available energy partitioned into sensible heat. However, the rather different energy partitioning over the carrot crop to the northwest of the instrument tower is clearly seen in Fig. 4. These data show that the sensible heat flux recorded by the ITE sonic was systematically smaller than those observed by the Bowenratio and aerodynamic systems when the fetch was across the carrot field. Such a discrepancy may be explained by differences in sensor calibration, but in this case is believed to be a reflection of the different "footprints" of each measuring system. The Bowenratio and wind-profile systems were measured predominantly over the stubble where latent heat fluxes were small. The flux footprint of the eddy covariance measurements lay mostly over the carrots where a greater proportion of the available energy was partitioned into latent heat and consequently less energy was available to be partitioned into sensible heat. A notable feature of both plots is the departure from linearity below zero. This is also a consequence of the difference in footprints, with the large negative sensible heat fluxes being observed by the sonic over the carrot crop. This is to be expected over a healthy canopy adequately supplied with water which, even during the night, will lose a small amount of water by transpiration as long as the surface layer remains turbulent. The energy for this process is mainly provided by a large sensible heat flux towards the ground. 

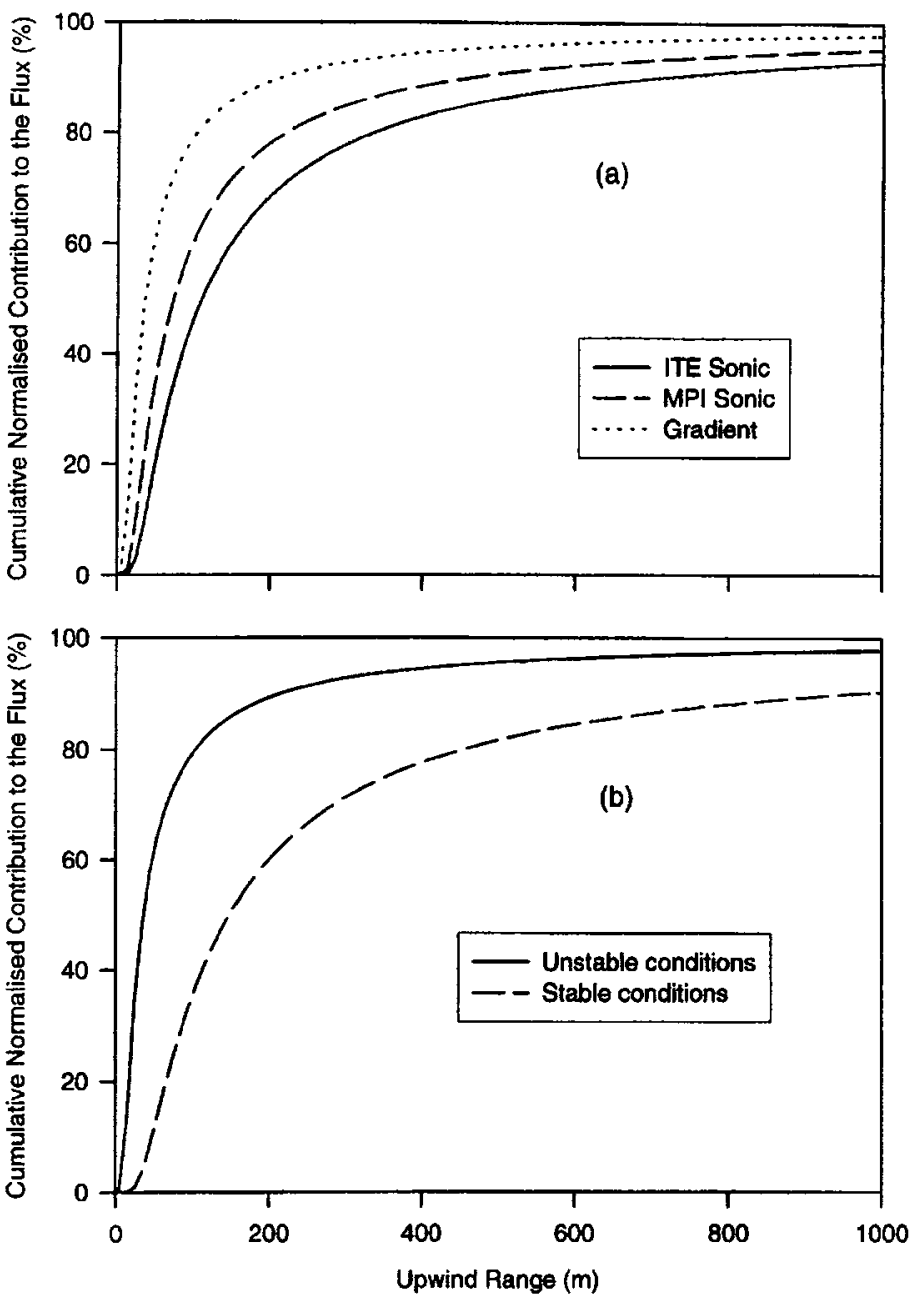

Fig. 2. (a) An example flux footprint for the Lammefjord site showing influence of different measuring heights (ITE Sonic, $4.9 \mathrm{~m}$; MPI Sonic, $3.25 \mathrm{~m}$; Gradient, $1.6 \mathrm{~m}$ ). (b) The effect of a change in atmospheric stability on the flux footprint of the gradient systems.

\section{Nitrous oxide fluxes}

Eddy covariance. The entire data sets of eddy covariance measurements by ITE and MPI are presented in Fig. 5 as a polar plot, to examine the directional dependence of $\mathrm{N}_{2} \mathrm{O}$ flux at the site. For example, if the soil under the carrot crop (in the $290-330^{\circ}$ sector) was a larger emitter than that under the wheat stubble, the fluxes from the NW sector would be larger than those from the SW. It is clear from Fig. 5 that no evidence for this exists, although there are systematic differences between adjacent sectors with a peak in emission rate in the $270^{\circ}$ sector. The magnitude of the flux measured by the two systems differs significantly (means of $313 \mu \mathrm{g} \mathrm{N} \mathrm{m} \mathrm{h}^{-1}$ from the ITE system and $224 \mu \mathrm{g} \mathrm{N} \mathrm{m}^{-2} \mathrm{~h}^{-1}$ from the MPI) but there is a distinct pattern to the measurements which is clearest in the $260-360^{\circ}$ sector. This discrepancy in measured flux cannot be accounted for either by differences in calibration standards (compared on site) or loss of flux due to inadequate instru- ment response time (Wienhold et al., 1994b; Zahniser et al., 1995).

One of the factors known to control $\mathrm{N}_{2} \mathrm{O}$ emission rate is soil temperature (McKenney et al., 1980); at this site the soil temperature varied between 11 and $17^{\circ} \mathrm{C}$ (at $10 \mathrm{~cm}$ depth) over the course of the experiment. This variability would, at most sites, be closely coupled with variability in $\mathrm{N}_{2} \mathrm{O}$ emissions but in this case no relationship between soil temperature and $\mathrm{N}_{2} \mathrm{O}$ emission rate was observed. This is attributed to the main source of $\mathrm{N}_{2} \mathrm{O}$ being between 0.75 and $1.05 \mathrm{~m}$ below the soil surface (Christensen et al., 1995), where soil temperature is little affected by such surface variations.

Flux gradient. Daily means of all the flux-gradient measurements are shown in Fig. 6. The magnitude of the gradients proved too small for detection by the SAC GC system, but the other techniques proved to have adequate sensitivity. On first inspection the agreement between the methods seems 

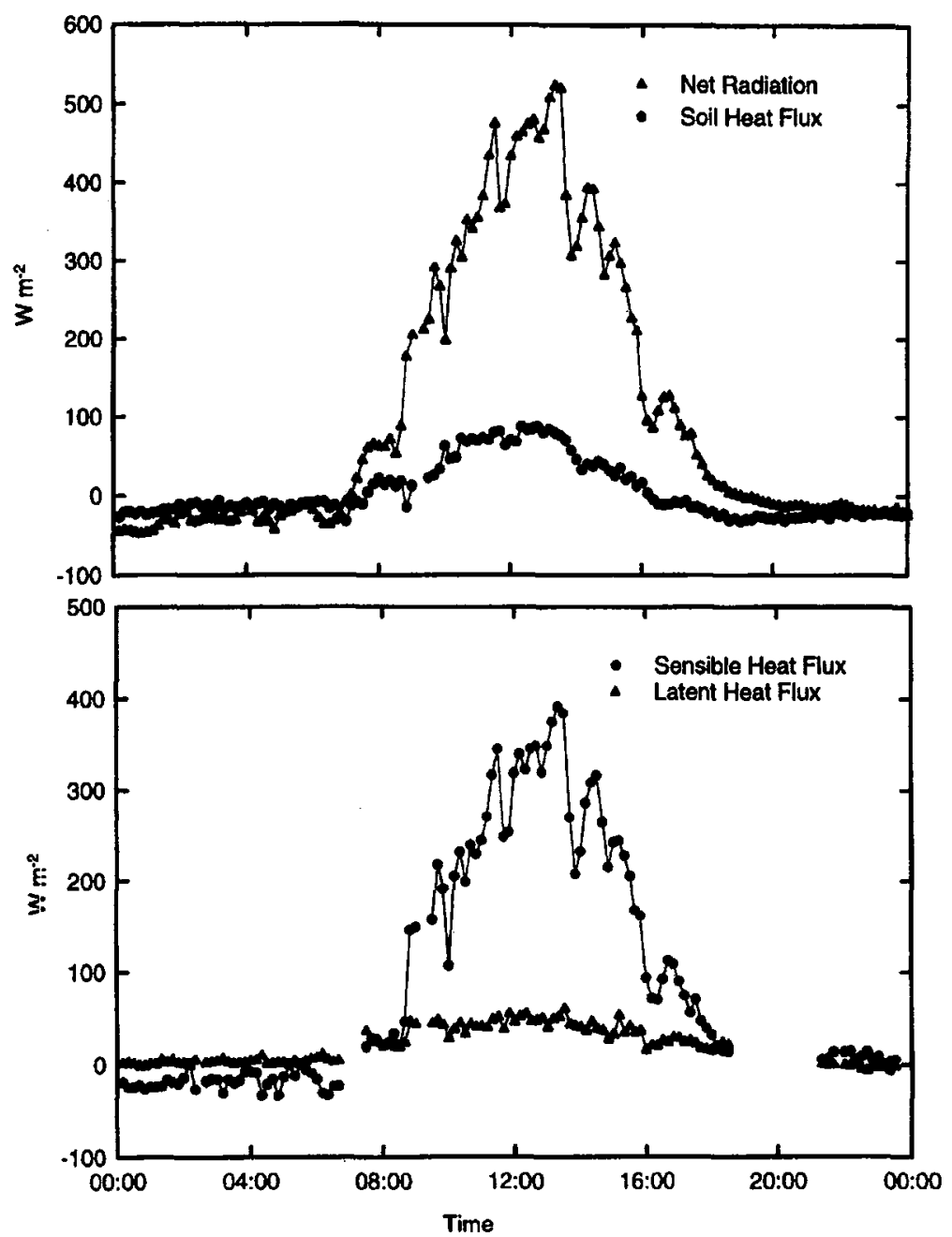

Fig. 3. Surface energy balance measured by the Bowen-ratio system at the Lammefjord site on 22 August 1993. Upper diagram shows net radiation and soil heat flux, lower diagram shows sensible and latent heat flux.

rather poor, but there are two points which must be considered:

(i) The only directly comparable measurements are those of IVL (IVL Swedish Environmental Research Institute) and MPI since they shared a common mast and measuring height range. However, simultaneous measurements were only made on 24 August, and while the IVL data represents continuous measurement on that day, the MPI data is from a $4 \mathrm{~h}$ period late in the afternoon. However, the mean emission rates measured on 24 August were in good agreement (IVL: $199 \mu \mathrm{g} \mathrm{Nm}^{-2} \mathrm{~h}^{-1}$, MPI: $203 \mu \mathrm{g} \mathrm{N} \mathrm{m} \mathrm{N}^{-2} \mathrm{~h}^{-1}$ ) (Christensen et al., 1995). The mean emission rate for all the IVL measurements was $149 \mu \mathrm{g} \mathrm{N} \mathrm{m}^{-2} \mathrm{~h}^{-1}$, and for MPIs was $203 \mu \mathrm{g} \mathrm{N} \mathrm{m}^{-2} \mathrm{~h}^{-1}$.

(ii) The ITE measurements were made over the same height range as those of MPI and IVL, but at a mast located $50 \mathrm{~m}$ to the northeast. It is therefore possible that the higher emission rates may simply be a reflection of an area of ground close to the mast which was emitting at a high rate. No chamber measurements are available to confirm this. It is also important to note that the majority of these measurements were made during neutral or mildly stable conditions, when the footprint of the measured flux would have extended much further upwind than during unstable daytime conditions. The mean emission rate for the ITE measurements was $326 \mu \mathrm{g} \mathrm{N} \mathrm{m}^{-2} \mathrm{~h}^{-1}$.

Conditional sampling. The conditional sampling system shared the same mast and sonic as the ITE eddy covariance system so the results are more directly comparable. The mean flux measured by conditional sampling was $379 \mu \mathrm{g} \mathrm{Nm}^{-2} \mathrm{~h}^{-1}$. These relatively high conditional sampling fluxes may be the result of overestimation of $\sigma_{\mathrm{w}}$ resulting from contamination of the vertical wind vector by horizontal 

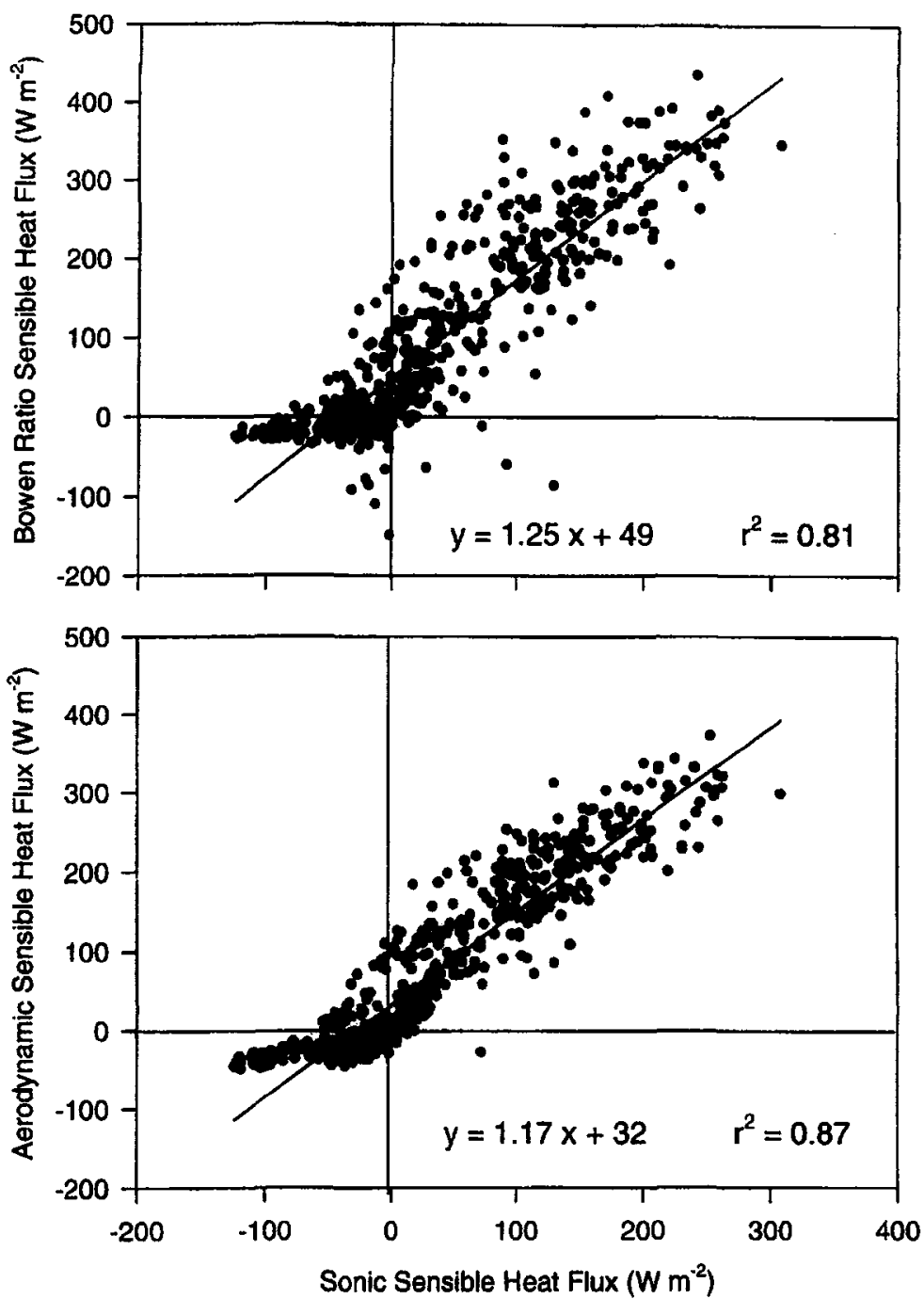

Fig. 4. Comparison of sensible heat fluxes from different measuring systems when the wind was blowing over the carrot crop. The upper diagram compares the Bowen-ratio and sonic data, the lower diagram compares the aerodynamic and sonic data.

wind fluctuations. However, intercomparisons of nonrotated heat fluxes computed by conditional sampling with rotated fluxes computed by eddy covariance suggest this was not an important factor. A further source of error may have been low frequency fluctuations of $w$. However, analytical errors associated with measuring the very small concentration differences $(\approx 0.2 \mathrm{ppb}$ ) may be a more significant source of error, although it is difficult to explain the systematically high measured fluxes.

\section{General discussion}

Some of the chamber results in this study showed an increase in emission rate as distance from the sampling mast increased (Fig. 7) and this may be used to illustrate the way in which nonuniformity of emission rates may produce systematic differences between micrometeorological methods operating at different heights. The emission rates shown in Fig. 7 were fitted by linear regression to produce a predicted emission rate for each $0.5 \mathrm{~m}$ of fetch out to $80 \mathrm{~m}$. Beyond this distance an assumption was made that the rate remained constant at the $80 \mathrm{~m}$ value. These data were then used to predict the flux measured at the three sensor heights under typical meteorological conditions. The results are summarised in Table 1 and, given the large approximations and assumptions made, give a satisfactory prediction of the measured flux. This illustrates the importance of placing chambers in such a way that their results can be usefully compared to those of micrometeorological methods. In future experiments it will be possible to address this problem by immediate footprint analysis of the individual micrometeorological flux measurements (Wienhold et al., 1995). It is also desirable to make all the micrometeorological measurements from a 


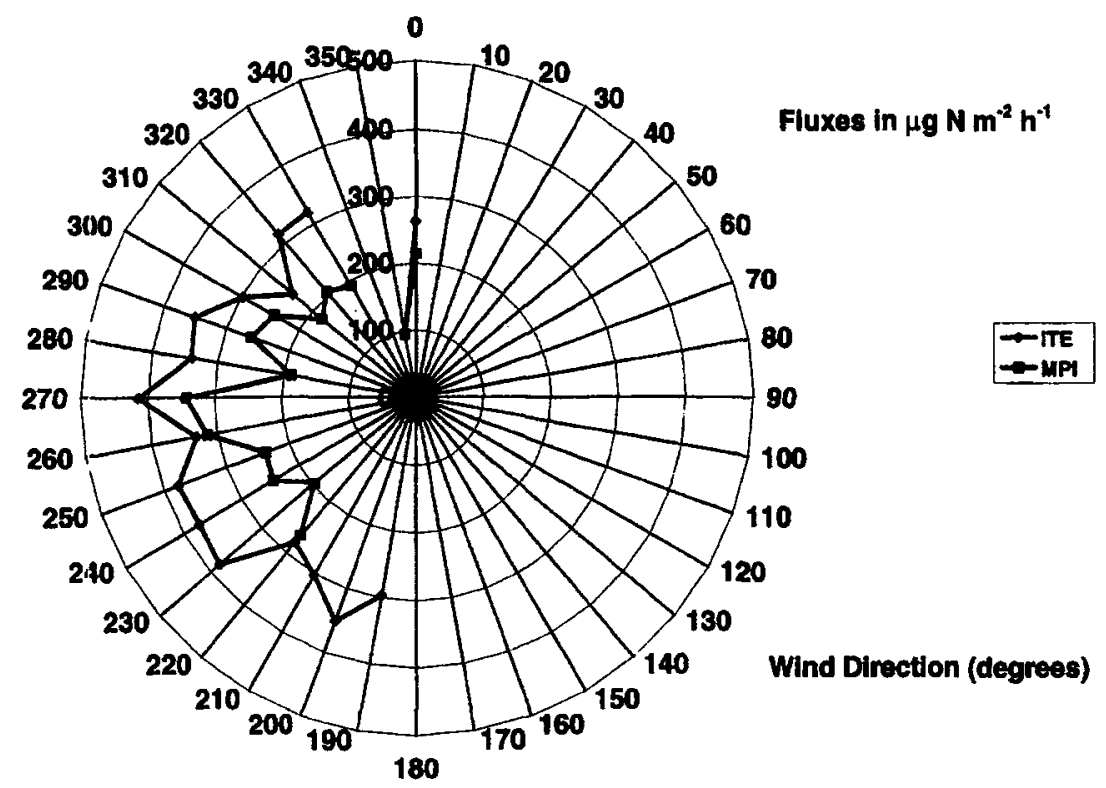

Fig. 5. Sector dependence of eddy covariance $\mathrm{N}_{2} \mathrm{O}$ fluxes at Lammefjord.

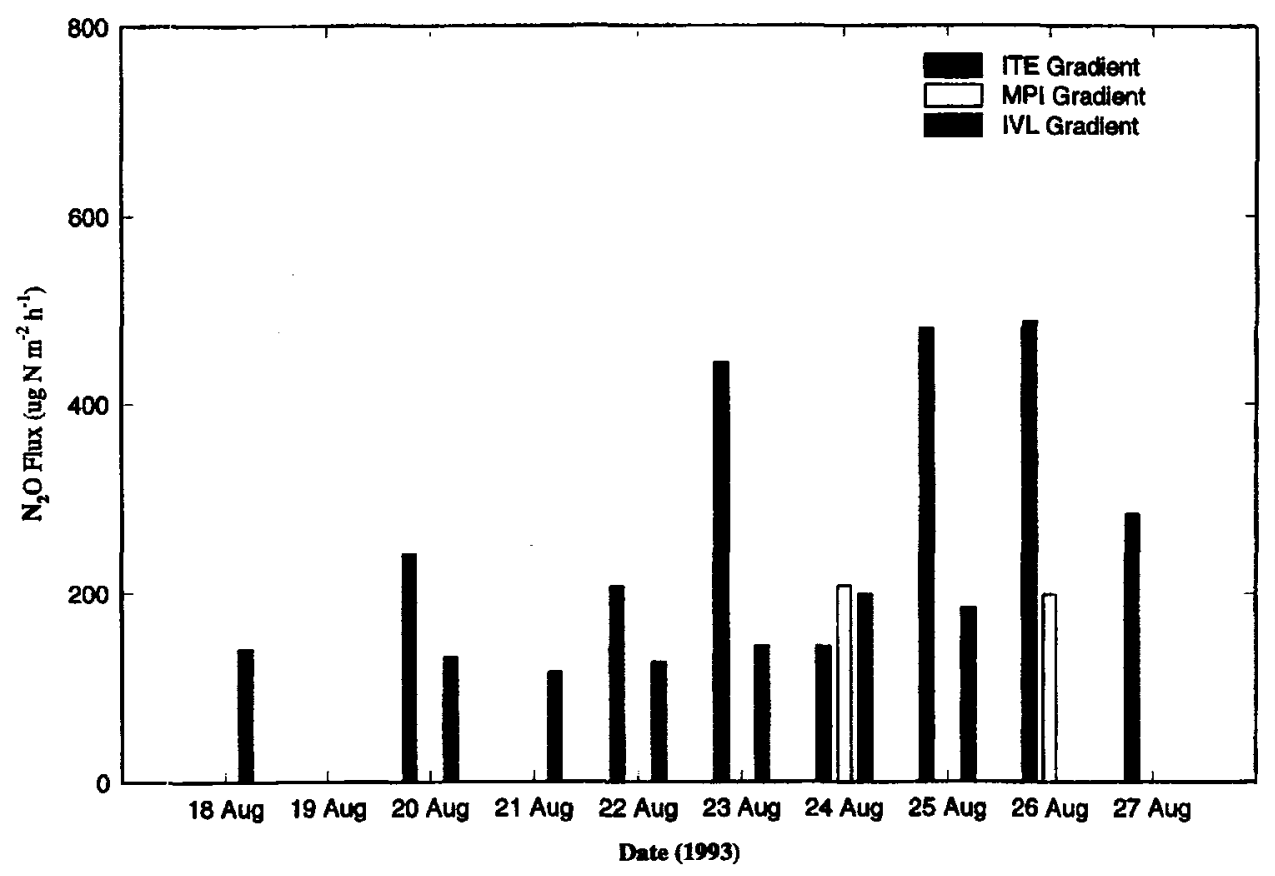

Fig. 6. Daily mean $\mathrm{N}_{2} \mathrm{O}$ fluxes determined by the three gradient techniques.

common mast and, if possible, at a common measuring height. This approach means that advection errors which can cause large variations in the measured flux (Fowler et al., 1995) are the same for all measurement systems.

Although the concept of footprinting may prove very useful in explaining fluxes measured at the field scale in terms of measurements made using chambers, in this study the spatial separation between the masts and the limited range over which it was practicable to install chambers mean that a full analysis cannot be made. Such problems are exacerbated by the nature of $\mathrm{N}_{2} \mathrm{O}$ emission, which is usually very variable both spatially and temporally. Similar difficulties were reported by Smith et al. (1994) during the first experiment in Scotland, where there was a clear boundary between an area of high emission and an area of low emission. In that case the micrometeorological 


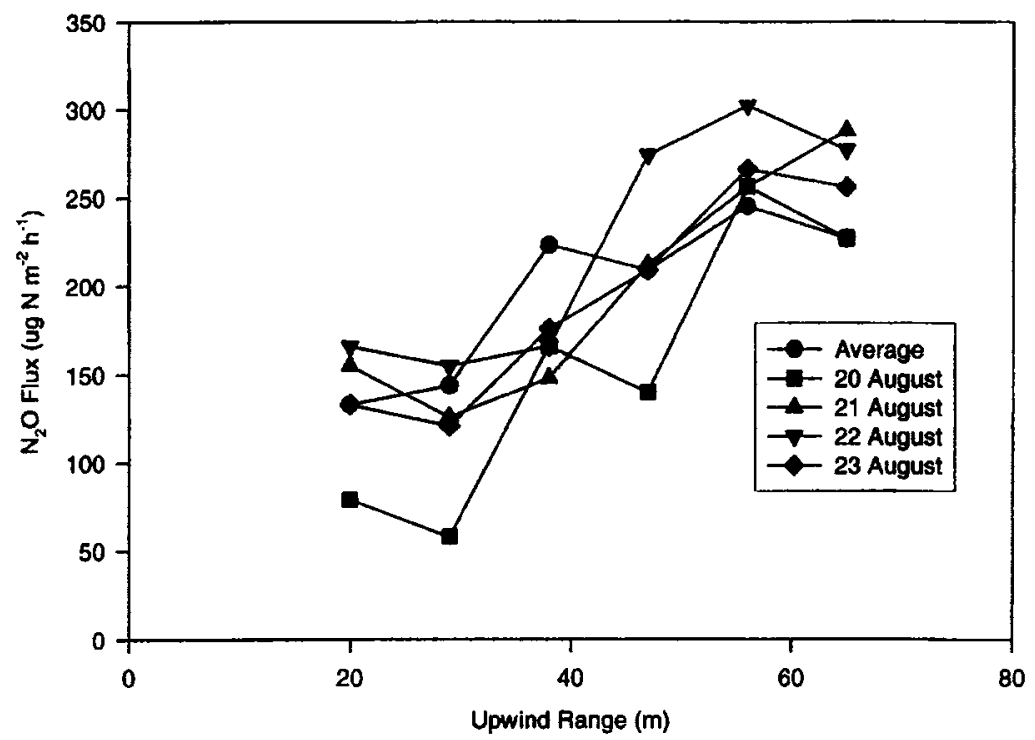

Fig. 7. Example chamber measurements of $\mathrm{N}_{2} \mathrm{O}$ emission upwind of the MPI/IVL mast.

Table 1. Measured and predicted fluxes of $\mathrm{N}_{2} \mathrm{O}$ from the Lammefjord field site

\begin{tabular}{lcc}
\hline Measurement method & $\begin{array}{c}\text { Measured flux } \\
\left(\mu \mathrm{g} \mathrm{m}^{-2} \mathrm{~h}^{-1}\right)\end{array}$ & $\begin{array}{c}\text { Predicted flux } \\
\left(\mu \mathrm{g} \mathrm{N} \mathrm{m}^{-2} \mathrm{~h}^{-1}\right)\end{array}$ \\
\hline $\begin{array}{l}\text { ITE eddy covariance } \\
(4.9 \mathrm{~m})\end{array}$ & 313 & 327 \\
$\begin{array}{c}\text { MPI eddy covariance } \\
(3.25 \mathrm{~m})\end{array}$ & 224 & 274 \\
Flux gradient $(1.6 \mathrm{~m})$ & 226 & 222 \\
\hline
\end{tabular}

systems were still under development and only limited quantities of data were available for direct comparison, but the placing of chambers in a region of high emissions undoubtedly contributed to the discrepancies between chamber and micrometeorological techniques. In the light of these previous difficulties, the relatively good agreement between the methods at the Danish site is very encouraging, in particular the dramatic improvements in reliability of the TDL systems.

The short duration of this experiment creates uncertainties in any estimation of the annual emissions from this site. However, the campaign occurred at a time of year when deep soil temperatures (and hence $\mathrm{N}_{2} \mathrm{O}$ emission rates) would be at or close to their maximum. It is therefore possible to specify a maximum potential emission factor based on the average of all the micrometeorological methods: this is $23.5 \mathrm{~kg}$ $\mathrm{Nha}^{-1} \mathrm{a}^{-1}$. Even assuming that the average rate for the whole year is only $20 \%$ of this maximum, this is a relatively large emission from an agricultural system which receives no artificial nitrogen fertiliser. For comparison, the emission rates measured by micrometeorological techniques in the previous experiment
(Hargreaves et al., 1994) spanned a similar range of values, even though the site had been previously grazed and $185 \mathrm{~kg} \mathrm{NH}_{4} \mathrm{NO}_{3} \mathrm{ha}^{-1}$ was applied just before the experiment began. This therefore implies that reclaimed land and, more significantly, intraestuarine regions may form a significant global source of $\mathrm{N}_{2} \mathrm{O}$ since they produce emission rates which are broadly similar to those from intensively managed pastures.

Acknowledgements-This work was supported by the Commission of the European Communities STEP programme (contract no. CT 900028), the United Kingdom Natural Environment Research Council TIGER programme (T03064H6) and the National Swedish Environmental Protection Board. The Scottish Office Agriculture and Fisheries Department funded the $\mathrm{N}_{2} \mathrm{O}$ diode for the ITE TDL system through the Scottish Agricultural College. We thank Soren Christensen and Per Ambus of the University of Copenhagen for the organisation of the experiment.

\section{REFERENCES}

Arah J. R. M., Crichton I. J., Smith K. A., Clayton H. and Skiba U. (1994) Automated gas chromatographic analysis system for micrometeorological measurements of trace gas fluxes. J. geophys. Res. 99, 16,593-16,598

Beveriand I. J., O Neill D. H., Scott S. and Moncrieff J. B. Design, construction and operation of flux measurement systems using the conditional sampling technique. Atmospheric Environment (submitted).

Businger J. A. (1986) Evaluation of the accuracy with which dry deposition can be measured with current micrometeorological techniques. J. Clim. appl. Met. 25, 1100-1124.

Businger J. A. and Oncly S. P. (1990) Flux measurement with conditional sampling. J. Atmos. Ocean. Technol. 7, 349-352. 
Christensen S., Ambus P., Arah J. R. M., Clayton H., Galle B., Griffith D. W. T., Hargreaves K. J., Klemedtsson L., Lind A.-M., Maag M., Scott A., Skiba U., Smith K. A., Welling M. and Wienhold F. G. (1995) $\mathrm{N}_{2} \mathrm{O}$ flux from an agricultural field determined from soil cover boxes, atmospheric gradients, conditional sampling and eddy covariance. Atmospheric Environment (submitted).

Fowler D. and Duyzer J. (1989) Micrometeorological techniques for the measurement of trace gas exchange. In Exchange of Trace Gases between Terrestrial Ecosystems and the Atmosphere (edited by Andreae M. O. and Schimel D. S.), pp. 189-207. Wiley, New York.

Fowler D., Hargreaves K. J., Skiba U., Milne R., Zahniser M. S., Moncrieff J. B., Beverland I. J. and Gallagher M. W. (1995) Measurements of $\mathrm{CH}_{4}$ and $\mathrm{N}_{2} \mathrm{O}$ fluxes at the landscape scale using micrometeorological methods. Phil. Trans. R. Soc. Lonaion (in press).

Galle B., Klemedtsson L. and Griffith D. W. T. (1994) Application of a Fourier transform IR system for measurements of $\mathrm{N}_{2} \mathrm{O}$ fluxe; using micrometeorological methods, an ultralarge chamber system and conventional field chambers. J. geophys. Res. 99, 16,575-16,584.

Hargreaves K. J., Skiba U., Fowler D., Arah J. R. M. Wienhold F. G., Klemedtsson L. and Galle B. (1994) Measurement of nitrous oxide emission from fertilised grassland using micrometeorological techniques. $J$. geophys. Res. 99, 16,569-16,574.

IPCC (1990) Climate Change, The IPCC Scientific Assessment. WMO/UNEP (edited by Houghton J. T., Jenkins G. J. and Ephraums J. J.). Cambridge University Press, Cambridge, U.K.

Leclerc M. Y. and Thurtell G. W. (1990) Footprint prediction of scalar flux using a markovian analysis. BoundaryLayer Met. 53, 247--258.

McKenney D. J., Shuttleworth K. F. and Findlay W. I. (1980) Temperature dependence of nitrous oxide production from Brookston Clay. Can. J. Soil Sci. 60, 665-674.

Moncrieff J. B., Massheder J. M., De Bruin H., Elbers J., Friborg T., Huetzenfeldt B., Kabat P., Scott S., Soogard H. and Verhoef A. (1994) A system to measure surface fluxes of momentum, sensible heat flux, water vapour and carbon dioxide. J. Hydrology (in press).

Monteith J. 1. and Unsworth M. H. (1990) Principles of Environmental Physics. Edward Arnold, London.

Schuepp P. H., Leclerc M. Y., MacPherson J. I. and Desjardins R. L. (1990) Footprint prediction of scalar fluxes from analytical solutions of the diffusion equation. BoundaryLayer Met. 50, 335-376.

Smith K. A., Clayton H., Arah J. R. M., Christensen S., Ambus P., Fowler D., Hargreaves K. J., Skiba U., Harris G. W., Wienhold F. G., Klemedtsson L. and Galle B. (1994) Micrometeorological and chamber methods for measurement of nitrous oxide fluxes between soils and the atmosphere: overview and conclusions. J. geophys. Res. 99, 16,541-16,548.

Webb E. K., Pearman G. I. and Leuning R. (1980) Correction of flux measurements for chemistry effects due to heat and water vapour transfer. Q.Jl R. Met. Soc. 106, 85-100.

Wienhold F. G., Zenter T. and Harris G. W. (1994a) A dual channel two tone frequency modulation tunable diode laser spectrometer for ground based and airborne trace gas measurements. In Tunable Diode Laser Spectroscopy, Lidar and DIAL Techniques for Environmental and Industrial Measurements (edited by Fried, Killinger and Schiff). Proc. SPIE 2112, 31-44.

Wienhold F. G., Frahm H. and Harris G. W. (1994b) Measurements of $\mathrm{N}_{2} \mathrm{O}$ fiuxes from fertilised grassland using a fast tunable diode laser spectrometer. J. geophys. Res. 99, 16,577-16,568.

Wienhold F. G., Welling M. and Harris G. W. (1995) Micrometeorological measurement and source region analysis of nitrous oxide emissions from an agricultural soil. Atmospheric Environment (submitted).

WMO (1992) Scientific Assessment of Ozone Depletion: 1991 WMO/UNEP, WMO Global Ozone Research and Monitoring Project, Report No. 25. Geneva.

Zahniser M. S., Nelson D. D., McManus J. B. and Kebabian P. L. (1995) Measurement of trace gas fluxes using tunable diode laser spectroscopy. Phil. Trans. R. Soc. London (in press). 